\title{
Cimetidine therapy does not prevent rebleeding from peptic ulceration
}

\author{
D. L. CARR-LOCKE \\ M.A., M.R.C.P.
}

D. TAVERNER

M.A., M.R.C.P.

\author{
A. C. B. WICKS* \\ M.D., F.R.C.P.
}

Department of Medicine, University of Leicester, Leicester Royal Infirmary, Leicester LE2 $7 L X$ and ${ }^{*}$ Leicester General Hospital, Leicester LE5 4PW

\begin{abstract}
Summary
One-hundred and five patients admitted to hospital with symptoms of acute upper gastrointestinal haemorrhage shown at endoscopy to be due to peptic ulceration were entered into a prospective doubleblind controlled trial of cimetidine versus placebo therapy. The trial therapy was commenced within 12 hr of admission and continued for 7 days. Cimetidine therapy made no difference to the transfusion requirements, rebleeding rate or number of operations performed in patients with either gastric or duodenal ulcers, nor was it of benefit in patients aged over 65 years of age.
\end{abstract}

KEY WORDS: gastric ulcer, duodenal ulcer, aspirin, vagotomy, pyloroplasty.

\section{Introduction}

The majority of patients with acute upper gastrointestinal haemorrhage will stop bleeding spontaneously after admission to hospital. There is, however, still an overall mortality of up to $10 \%$, most marked in the elderly and those who rebleed after admission (Allen and Dykes, 1976). Following rebleeding, surgical mortality may be as high as $\mathbf{2 8 . 8 \%}$ compared with $7.8 \%$ in those who do not rebleed (Jones et al., 1973). Therapy that reduced the incidence of rebleeding would therefore be expected to lower mortality substantially.

Raising intragastric $\mathrm{pH}$ reduces local fibrinolysis and increases platelet aggregation (Green et al., 1978) and provides a possible basis for the prevention of rebleeding. Oral antacid administration in doses sufficient to neutralize gastric acid is inconvenient and may have systemic side effects in elderly patients.

Address for correspondence: Dr. D. Taverner, Department of Medicine, Clinical Sciences Building, Leicester Royal Infirmary, Leicester LE2 7LX.
The $\mathrm{H}_{2}$-antagonist, cimetidine, is a potent inhibitor of basal and stimulated gastric acid secretion (Bur-? land et al., 1975), reducing the blood loss from experimental gastric erosion (Odonkor, Mowat and Himal, 1981). It might therefore be expected to reduce the likelihood of recurrent bleeding within a 9 few days of an initial haemorrhagic episode, and is frequently given in this clinical situation, usually $\subset$ intravenously. However published studies of cimetidine in bleeding ulcer disease have not convincingly shown that it is of benefit, and such therapy $\mathscr{C}_{\mathscr{O}}$ expensive and potentially toxic. We therefore unde? + took a prospective double-blind controlled study test the possible benefits of cimetidine therapy after hospital admission for bleeding peptic ulceration.

\section{Patients and methods}

One-hundred and thirty consecutive patients admitted to Leicester General Hospital during an 18month period with symptoms of acute upper gastrointestinal bleeding were entered into the trial with the $\bar{c}$ prior approval of the Area Ethical Committee, the physician in charge and the informed consent of the patient. Those requiring immediate surgery for continuing uncontrolled haemorrhage were excluded.

A careful history was taken particularly with regard to previous illness and ingestion within the 9 previous 14 days of salicylates and other drugs $D$ capable of causing upper gastrointestinal symptoms. Fibreoptic oesophagogastroduodenoscopy was per- $N$ formed within $6 \mathrm{hr}$ of admission by an experienced endoscopist. One-hundred and five patients with a O $^{\circ}$ gastric ulcer (GU) or duodenal ulcer (DU) identified $\mathrm{N}_{\mathrm{J}}$ as the likely source of blood loss (defined by the presence of fresh or old blood or clot in the ulcer base 0 or a visible vessel) were given cimetidine or a placebo $\mathbb{D}$ of identical appearance on a double-blind basis. $\stackrel{?}{\rightarrow}$ Drug allocation followed endoscopic diagnosis and 7 was stratified for diagnosis and age above and below 
65 years. Cimetidine was given as an initial $200 \mathrm{mg}$ intravenous bolus followed by a continuous infusion of $1200 \mathrm{mg}$ daily for 2 days. After this cimetidine tablets ( $200 \mathrm{mg}$ tds, $400 \mathrm{mg}$ nocte) were administered for a total of 7 days. Placebo was given as an identical regimen of injection and tablets. Concomitant therapy consisted of antacids as required to relieve symptoms and a normal diet within $48 \mathrm{hr}$ of admission. Blood and plasma substitutes were given as clinically indicated.

Following the initiation of therapy, fresh melaena, haematemesis, significant tachycardia or a hypotensive episode were considered to be due to recurrent or continued bleeding and the patient was withdrawn from the trial.

Statistical analysis used Student's t-test and the chi-squared test with Yates' correction, as appropriate; significance was determined at the level of $P<0.05$.

\section{Results}

From a consecutive series of 130 patients who presented with acute upper gastrointestinal bleeding, 105 patients with peptic ulcers were entered into the trial. Fifty-one patients had a GU, 54 had a DU on endoscopy and their clinical details are summarized in Table 1. Severe haemorrhage was defined as the presence of at least one of the following; a history of syncope, a tachycardia of more than $100 / \mathrm{min}$, or a systolic blood pressure less than $100 \mathrm{mmHg}$ on admission.
Recurrent bleeding occurred in $32 \%$ of the GU and $28 \%$ of the DU group. Those patients with GU who had a history of irritant drug ingestion had a much lower rate of rebleeding $(6 / 30 ; 20 \%)$ than those patients with no such history $(10 / 21 ; 48 \%, P<0.05)$. GU patients with a previously diagnosed $G U$ were significantly more likely to rebleed after admission $(9 / 17 ; 53 \%)$ than those without such a history $(7 / 34$; $21 \%, P<0.02)$. These differences were not present in the DU group.

Cimetidine therapy had no effect on the rebleeding rate (Table 2). In patients with $\mathrm{GU}, 31 \%( \pm 8 \%$, s.e.m.) of the placebo-treated patients rebled compared to $32 \%( \pm 9 \%)$ of the cimetidine-treated; the difference is non-significant. Patients with DU similarly showed no benefit from cimetidine. Placebo treatment was associated with a $24 \%( \pm 7 \%)$ rebleeding rate, while cimetidine therapy carried a $31 \%$ $( \pm 8 \%)$ rate. Neither was any difference apparent when groups were analysed for age above 65 years, or in those who presented with severe haemorrhage. Antacids were consumed in insignificant amounts by all groups.

Surgical treatment for recurrent bleeding was required in seven (14\%) of GU patients and six (11\%) of those with DU; this was unaltered by cimetidine therapy. Details of surgery are presented in Table 3. No post-operative deaths or serious complications occurred. There were two deaths during rebleeding episodes, both in old women aged 78 and 87 years, with other medical illness (senile dementia, hepatic cirrhosis) who did not undergo surgery.

TABLE 1. Clinical details of patients

\begin{tabular}{lcc}
\hline Group & $\begin{array}{c}\text { Gastric } \\
\text { ulcer }\end{array}$ & $\begin{array}{c}\text { Duodenal } \\
\text { ulcer }\end{array}$ \\
\hline Number & 51 & 54 \\
Age (years \pm s.d.) & $68 \cdot 4 \pm 15 \cdot 7$ & $61 \cdot 6 \pm 14 \cdot 5$ \\
Male/female & $27 / 24$ & $43 / 11$ \\
Presenting symptoms of haematemesis (\%) & 14 & 20 \\
Presenting symptoms of melaena (\%) & 37 & 45 \\
Presenting symptoms of haematemesis and melaena (\%) & 49 & 35 \\
Severe haemorrhge (\%) & 80 & 65 \\
History of peptic ulcer (\%) & 33 & 37 \\
History of major medical illness (\%) & 31 & 33 \\
Irritant drug ingestion (\%) & 59 & 46 \\
Haemoglobin on admission (mean, range g/dl) & $9 \cdot 2(4 \cdot 7-16 \cdot 9)$ & $9 \cdot 7(2 \cdot 8-14.9)$ \\
Transfusion requirement (median, range units) & $4(0-15)$ & $3(0-9)$ \\
\hline
\end{tabular}

TABLE 2. Lack of influence of cimetidine on rebleeding

\begin{tabular}{llccc}
\hline & Treatment & (Number of patients) & No rebleed & Rebleed \\
\hline Gastric ulcer & Cimetidine & $(22)$ & 15 & 7 \\
& Placebo & $(29)$ & 20 & 9 \\
Duodenal ulcer & Cimetidine & $(29)$ & 20 & 9 \\
& Placebo & $(25)$ & 19 & 6 \\
\hline
\end{tabular}


TABLE 3. Surgery required for rebleeding

\begin{tabular}{|c|c|c|c|c|c|}
\hline \multirow{2}{*}{$\begin{array}{l}\text { Group } \\
\text { GU } \\
\text { over } 65 \text { years old }\end{array}$} & \multicolumn{2}{|c|}{$\begin{array}{l}\text { Patient } \\
\text { Age/Sex }\end{array}$} & \multirow{2}{*}{$\begin{array}{l}\text { Treatment } \\
\text { Cimetidine }\end{array}$} & \multirow{2}{*}{$\begin{array}{c}\begin{array}{c}\text { Days after } \\
\text { admission }\end{array} \\
\\
3,5 \\
4,2 \\
4,3\end{array}$} & \multirow{2}{*}{$\begin{array}{l}\text { Operation (number performed) } \\
\\
\text { Underrun (1) } \\
\text { Billroth 1 (3) } \\
\text { Underrun (1) } \\
\text { V \& P (1) }\end{array}$} \\
\hline & $\begin{array}{l}68 / \mathrm{m} \\
84 / \mathrm{f} \\
73 / \mathrm{f}\end{array}$ & $\begin{array}{l}77 / f \\
89 / f \\
78 / f\end{array}$ & & & \\
\hline $\begin{array}{l}\text { GU } \\
\text { under } 65 \text { years old }\end{array}$ & $57 / \mathrm{m}$ & & Placebo & 2 & $\begin{array}{l}\text { Roux-en-Y and vagotomy } \\
\text { (previous Polya gastrectomy) }\end{array}$ \\
\hline $\begin{array}{l}\text { DU } \\
\text { over } 65 \text { years old }\end{array}$ & $\begin{array}{l}83 / f \\
67 / m\end{array}$ & $81 / \mathrm{m}$ & $\begin{array}{l}\text { Cimetidine } \\
\text { Placebo }\end{array}$ & $\begin{array}{l}4 \\
1,6\end{array}$ & $\begin{array}{l}V \& P \\
V \& P\end{array}$ \\
\hline $\begin{array}{l}\text { DU } \\
\text { under } 65 \text { years old }\end{array}$ & $\begin{array}{l}45 / \mathrm{m} \\
26 / \mathrm{m}\end{array}$ & $63 / \mathrm{f}$ & $\begin{array}{l}\text { Cimetidine } \\
\text { Placebo }\end{array}$ & 2,2 & $\begin{array}{l}V \& P(2) \\
V \& P\end{array}$ \\
\hline
\end{tabular}

$\mathrm{V} \& \mathrm{P}=$ vagotomy and pyloroplasty; $\mathrm{GU}=$ gastric ulcer; $\mathrm{DU}=$ duodenal ulcer.

\section{Discussion}

There have been several previous trials of cimetidine in acute upper gastrointestinal bleeding. Prophylactic therapy with cimetidine reduces the blood loss due to gastric erosions in selected high-risk patients (Speranza, Basso and Bagarani, 1981). Prospective double-blind placebo-controlled trials of the efficacy of cimetidine in haemorrhage due to peptic ulceration have shown conflicting results. La Brooy et al. (1979) studied 101 patients in a multicentre trial, giving cimetidine $800 \mathrm{mg}$ orally at entry and $1.2 \mathrm{~g}$ daily or placebo. Of all patients in the trial, 11 of 51 on cimetidine rebled compared to 12 of 50 on placebo; cimetidine was of no benefit in the elderly, in severe bleeding, or in the 70 patients who had a peptic ulcer identified at endoscopy. Similarly Hoare, Bradby and Hawkins (1979) reported a trial of 66 patients admitted with bleeding peptic ulceration; results on the first $\mathbf{4 0}$ patients in this trial had been previously published (Dykes and Hoare, 1977). Of patients with DU, only 2 of 14 treated with cimetidine rebled compared to 10 of 19 on placebo, the majority of these patients were over 65 years old and cimetidine significantly reduced rebleeding in the elderly group $(P<0.05)$. No such benefit was seen in patients with DU. Carstenson et al. (1980) studied a group of 88 patients admitted with severe haemorrhage requiring immediate transfusion: $30 \%$ of all patients with peptic ulcers required surgery within an average of $19 \mathrm{hr}$ after admission, and cimetidine made no difference to the transfusion requirements or the need for further surgery. In 96 patients with less severe haemorrhage (patients with arterial bleeding visible at endoscopy were excluded), Galmiche $e t$ al. (1980) gave cimetidine $1.6 \mathrm{~g} /$ day iv for 3 days followed by 4 days oral treatment. He found that patients with a GU were significantly less likely to rebleed if given cimetidine, as were patients over 50 years old and those taking anti-inflammatory analgesics before admission. Two further trials of cimeti- 을 dine versus placebo have shown no benefit of cimetidine but the numbers of patients were too small $\subseteq$ to reliably detect a possible difference (Pickard et al., 1979; Macklon, Roberts and James, 1979).

In a study of this nature, the numbers of patients each diagnostic category and the rate of rebleeding (i.e. the test of efficacy of cimetidine) determine the chance that the trial will fail to detect a genuine benefit of cimetidine treatment. Small groups and a low rate of rebleeding increase the likelihood of such a type II statistical error (Feinstein, 1977).

Even though our study contains the largest number $\overrightarrow{\vec{B}}$ of patients in each category (GU and DU), and has a similar rate of rebleeding to previous studies, we $\bar{\partial}$ would expect to detect only a $16 \%$ change in the overall rate of rebleeding due to cimetidine with $95 \%$ 들 confidence; none of the previous trials provide this power.

We could not confirm the suggestion that elderly patients with GU benefitted from cimetidine (Hoare $ᄋ$ et al., 1979), neither did treatment delay the need for emergency surgery or the transfusion requirement. ㅇ The overall mortality rate was low (two deaths) since $>$ the trial was designed to exclude patients with lifethreatening and continued haemorrhage, who generally undergo emergency surgery after resuscitation. $O$ Patients with a GU who had either a past history of $N$ peptic ulceration or had not taken aspirin-like drugs $N_{\mathrm{W}}$ prior to admission were particularly likely to rebleed. These patients are an identifiable high-risk subgroup 0 in which further trials of therapy to prevent rebleeding are needed.

We conclude that cimetidine therapy does not $D$ significantly influence the rebleeding rate within $7 \stackrel{0}{\mathbb{Q}}$ 
days of admission to hospital with a bleeding peptic ulcer. Cimetidine therefore has no rational place in the early management of bleeding peptic ulcer except to initiate healing; this can be achieved equally well be enteral therapy when oral intake has been resumed.

\section{Acknowledgments}

We thank the Consultant Physicians of Leicester General Hospital and their patients who agreed to participate in this study and the staff of the Leicester General Hospital Endoscopy Unit. We are grateful for the secretarial assistance of Rosalind Aldwinckle.

\section{References}

ALLEN, R. \& DYKes, P. (1976) A study of the factors influencing mortality rates from gastrointestinal haemorrhage. Quarterly Journal of Medicine, 180, 533.

Burland, W.L., Duncan, W.A.R., Hesselbo, T., Mills, J.G., ShaRPE, P.C., HAGgIE, S.J. \& WYLlIE, J.H. (1975) Pharmacological evaluation of cimetidine, a new histamine $\mathbf{H}_{2}$ antagonist in healthy man. British Journal of Pharmacology, 2, 481.

Carstenson, H.E., Bolow, S., hansen, O.H., Jakobsen, B.H., Krarup, T., Pederson, T., RaAhaue, D., Svendsen, L.B. \& BACKER, O. (1980) Cimetidine for severe gastrointestinal haemorrhage: a randomised controlled trial. Scandinavian Journal of Gastroenterology, 15, 103.

DYKES, P.W. \& HOARE, A. (1978) Treatment of upper gastrointestinal haemorrhage with cimetidine. In: Creutzfeldt, W., ed. Proceedings of an International Symposium on Histamine $\mathrm{H}_{2}$-receptor
Antagonists, 1977. (Ed. W. Creutzfeldt), p. 271. Excerpta Medica, Amsterdam.

FeINSTEIN, A.R. (1977) Clinical Biostatistics. C.V. Mosby, St. Louis. Galmiche, P.J., Colin, R., Vegrac, M., Hecketsweiter, P., OUVRY, D., Teniere, P. \& DuCrotTe, P. (1980) Double-blind controlled trial of cimetidine in bleeding peptic ulcer. In: $\mathrm{H}_{2^{-}}$ antagonists: Proceedings of a European symposium. (Ed. A. Torsoli), p. 164. Excerpta Medica, Amsterdam.

Green, F.W., KaPlan, M.M., CuRTIS, L.E. \& LeVine, P.H. (1978) Effect of acid and pepsin on blood coagulation and platelet aggregation. Gastroenterology, 74, 38.

Hoare, A.M., BRADBY, G.V.H. \& Hawkins, C.F. (1979) Cimetidine in bleeding peptic ulcer. Lancet, if, 671 .

Jones, P.F., Johnston, S.J., McEwan, A.B., Kyle, J. \& NeedHAM, C.D. (1973) Further haemorrhage after admission to hospital for gastrointestinal haemorrhage. British Medical Journal, 3,660 .

LA BroOY, S.J., Misiewicz, J.J., EdWARdS, J., SMITH, P.M., HAGgIe, S.J., LibMan, L., SARner, M., Wyllie, J.H., CroKer, J. \& CotTon, P. (1979) Controlled trial of cimetidine in upper gastrointestinal haemorrhage. Gut, 20, 892.

MACKLON, A.F., ROBERTS, S.H. \& JAMES, O. (1979) Cimetidine in bleeding peptic ulcers (letter). Lancet, ii, 1135.

ODONKOR, P., MOWAT, C. \& HimaL, H.S. (1981) Prevention of sepsis-induced gastric lesions in dogs by cimetidine. Gastroenterology, 80, 375.

Pickard, R.G., Sanderson, I., South, M., Kirkham, J.S. \& NORTHFIELD, T.C. (1979) Controlled trial of cimetidine in acute upper gastrointestinal bleeding. British Medical Journal, 1, 661 .

Speranza, V., Basso, N. \& Bagarani, M. (1981) Prevention of bleeding with cimetidine. In: Cimetidine in the 80's (Ed. J. H. Baron), p. 190. Churchill Livingstone, Edinburgh.

(Accepted 26 October 1983) 